\title{
UJI LAJU PEMBAKARAN DAN NILAI KALOR BRIKET WAFER SEKAM PADI DENGAN VARIASI TEKANAN
}

\author{
Muh. Arafatir Aljarwi'1), Dwi Pangga ${ }^{1)}$, Sukainil Ahzan'1) \\ ${ }^{1)}$ Program Studi Pendidikan Fisika, Fakultas Sain, Teknik, dan Terapan, Universitas Pendidikan Mandalika, Mataram, Nusa \\ Tenggara Barat, Indonesia \\ Corresponding author : Muh. Arafatir Aljarwi \\ E-mail : muharafatiraljarwi@gmail.com
}

\section{Diterima 22 Agustus 2020, Disetujui 14 September 2020}

\begin{abstract}
ABSTRAK
Penelitian ini bertujuan untuk mengetahui laju pembakaran dan nilai kalor briket wafer sekam padi dengan variasi tekanan. Proses pembuatannya dengan menggunakan alat tekan briket, bahan yang digunanakan yaitu sekam padi dan tepung kanji. Hasil densitas briket wafer sekam padi dengan variasi tekanan secara berurut 20 PSI yaitu sebesar $0,453 \mathrm{~g} / \mathrm{cm}^{3}, 30$ PSI yaitu sebesar $0,467 \mathrm{~g} / \mathrm{cm}^{3}$, dan 40 PSI yaitu sebesar $0,500 \mathrm{~g} / \mathrm{cm}^{3}$. Nilai kalor briket wafer sekam padi dengan variasi tekanan secara berurut 20 PSI yaitu sebesar 4.793,94 kalori, 30 PSI yaitu sebesar 5.137,64 kalori, 40 PSI yaitu sebesar $5.266,52$ kalori. Kadar air yang dihasilkan dengan variasi tekana secara berurut 20 PSI yaitu sebesar $6,45 \%, 30$ PSI yaitu sebesar 6,40 \%, 40 PSI yaitu sebesar 5,65 \%. Nilai laju pembakaran briket wafer sekam padi secara berurut $20 \mathrm{PSI}$ yaitu sebesar 2,2212 $\mathrm{gram} / \mathrm{menit}$, $30 \mathrm{PSI}$ yaitu sebesar 2,2878 gram/menit, $40 \mathrm{PSI}$ yaitu sesar 2,4363 gram/menit. Dapat disimpulkan bahwa semakin besar tekanan maka nilai kalor dan laju pembakaran dari briket wafer sekam padi akan semakin meningkat.
\end{abstract}

Kata kunci: sekam padi; briket; nilai kalor; laju pembakaran.

\begin{abstract}
This study aims to determine the combustion rate and heating value of rice husk wafer briquettes with variations in pressure. The manufacturing process uses briquette press, the ingredients used are rice husk and starch. The results of the density of rice husk wafer briquettes with a sequence of $20 \mathrm{PSI}$ pressure variations in the amount of $0.453 \mathrm{~g} / \mathrm{cm} 3,30 \mathrm{PSI}$ in the amount of $0.467 \mathrm{~g} / \mathrm{cm} 3$, and $40 \mathrm{PSI}$ in the amount of $0.500 \mathrm{~g} / \mathrm{cm} 3$. The calorie value of rice husk wafer briquettes with a variety of sequential pressure variations of $20 \mathrm{PSI}$ is $4,793.94$ calories, $30 \mathrm{PSI}$ is $5,137.64$ calories, $40 \mathrm{PSI}$ is $5,266.52$ calories. The resulting water content with a variety of pressures in sequence $20 \mathrm{PSI}$ is $6.45 \%, 30 \mathrm{PSI}$ is $6.40 \%, 40 \mathrm{PSI}$ is $5.65 \%$. The value of the rate of burning of rice husk wafer briquettes in sequence of $20 \mathrm{PSI}$ is 2.22212 grams / minute, $30 \mathrm{PSI}$ is $2.22878 \mathrm{grams}$ / minute, $40 \mathrm{PSI}$ is 2.4363 grams / minute fault. It can be concluded that the greater the pressure, the calorific value and the rate of combustion of rice husk wafer briquettes will increase.
\end{abstract}

Keywords: rice husk; briquettes; heating value; rate of increase.

\section{PENDAHULUAN}

Mayoritas masyarakat Lombok pekerjaanya adalah sebagai petani. Salah satu komoditas yang ditanam oleh petani di pulau Lombok yaitu tembakau (nicotiana tubacum). Tanaman ini berasal dari Amerika utara dan Amerika selatan yang bisa hidup di daerah yang beriklim tropis. Tembakau yang dihasilkan di pulau Lombok memiliki kualitas yang bagus sehingga mampu bersaing dengan produk impor (Hamidi, 2007). Pada tahun 2019 berdasarkan informasi dari dinas pertanian dan perkebunan provinsi NTB, luas area tanam tembakau mencapai 25.000 hektar dengan hasil produksi kering mencapai 50.000 ton (Anonim, 2019). Dengan hasil tersebut NTB menjadi pemasok tembakau terbesar di tanah air.

Sebelum dipasarkan tembakau harus melalui proses pengovenan terlebih dahulu. Dalam proses pengovenan diperlukan bahan bakar untuk membuat tembakau kering dan menghasilkan tembakau yang berkualitas sesuai dengan permintaan pasar. Bahan bakar yang selama ini masyarakat gunakan dalam proses pengovenan adalah kayu. Apabila bahan bakar kayu terus digunakan oleh masyarakat maka beberapa tahun kedepan akan berdampak ke pada lingkungan. Dampak negatif dari penebangan pohon yaitu akan menyebabkan rendahnya kualitas oksigen, kekeringan, erosi tanah dan pemanasan global. 
Untuk menghindari dampak negatif yang ditimbulkan karena pemanfaatan kayu sebagai bahan bakar oven tembakau maka perlu adanya bahan bakar alternatif yang dapat menggantikan kayu sebagai bahan bakar pengovenan tembakau.

Pemanfaatan lahan Desa Jerowaru diambil dari profil Desa Jerowaru pada tahun 2020. Jenis penggunaan lahan berupa tanah sawah seluas 1.388,18 hektar, bangunan dan pekarangan 75,80 hektar, tegal dan kebun 89,00 hektar dan lainnya 120,02 hektar. Penggunaan lahan di Desa Jerowaru sebagian besar diperuntukan untuk tanah sawah pertanian, sedangkan sisanya untuk tanah kering yang merupakan bangunan dan fasilitasfasilitas lainnya. Secara umum mata pencaharian penduduk Desa Jerowaru didominasi sebagai petani 3.319 orang sehingga sektor pertanian menjadi penggerak utama ekonomi masyarakat. Pada tahun 2020 hasil pertanian dari komoditas padi yaitu sebesar 8.329,08 ton per tahun. komuditas ini ditanam oleh masyarakat setiap tahunnya pada musim penghujan sehingga pada hasil akhir sebelum menjadi beras, padi akan digiling dan sekamnya akan ditumpuk dipenggilingan dan tidak dimanfaatkan.

Salah satu bahan bakar alternatif yang dapat menggantikan kayu yaitu biomassa. Biomassa adalah bahan organik yang dihasilkan melalui proses fotosintesis, baik berupa produk maupun buangan. Contoh biomassa antara lain adalah tanaman, pepohonan, rumput, limbah hutan, kotoran ternak dan limbah pertanian (Patabang, 2016). Bio massa secara umum berasal dari material kering organik dari tanaman dan kotoran hewan (Sunaryo, 2014). Slulosa dan lignin merupakan komponen utama dari biomasa, biomasa sangan potensial untuk dikembangkan karena memiliki kandungan energi berkisar antara 3000-4500 kal/gr (Arni L., Hosiana M.D.. dan Nismayanti A., 2014). Salah satu biomassa yang bisa dimanfaatkan menjadi bahan bakar alternatif pengganti kayu adalah sekam padi. Sekam padi mudah didapat dan banyak ditemukan di daerah pedesaan. Selulosa yang terkandung dalam sekam padi dapat memberikan pembakaran yang merata dan setabil sehingga dapat dimanfaatkan sebagai sumber energi pengganti minyak dan kayu (Muhammad kardi \& Rugaya, 2013).

Agar biomassa dapat digunakan secara efektif maka perlu dilakukan pembriketan. Beriket merupakan hasil pengempaan bahan bakar yang berbentuk padat berukuran kecil (Agustina dan Safrian, 2005). Bahan bakar briket juga merupakan bahan bakar yang dibuat dari biomassa yang dikonversi kebentuk lain, biomassa diolah sehingga bentuknya lebih teratur (Hendra, 2008). Kualitas briket ditentukan dari bahan yang digunakan, konsentrasi perekat, perekat yang digunakan, dan kuat tekan. Berdasarkan latar belakang di atas peneliti ingin meneliti tentang uji kualitas briket dengan kuat tekan yang berbeda untuk menentukan laju dan nilai kalor yang dihasilkan.

\section{METODE PENELITIAN Jenis Penelitian}

Jenis penelitian yaitu penelitian exsperimen yang dilaksanakan di laboratorium fisika UNDIKMA.

\section{Waktu dan Tempat Penelitian}

Penelitian dilaksanakan pada bulan Desember 2019 - Juni 2020, di Laboratorium Fisika dan Kimia Fakultas Sains, Teknik dan Terapan Universitas Pendidikan Mandalika Mataram.

\section{Instrumen Penelitian}

Dalam penelitian ini alat dan bahan yang digunakan yaitu besi pagar berfungsi pada saat melakukan proses pengarangan (karbonisasi), alat pencetak briket wafer sekam padi berfungsi untuk mencetak beriket, korek api berfungsi untuk membakar dalam proses pengarangan (karbonisasi) dan pengujian pembakaran, stopwatch untuk menghitung lama waktu pembakaran briket sampai menjadi abu, timbangan digital untuk menimbang bahan baku briket, bak tempat pencampuran bahan, dan ember tempat peletakan bahan. Sedangkan bahan yang digunakan yaitu sekam padi sebagai bahan utama pembuatan briket wafer, tepung kanji sebagai perekat, minyak curah (sisa) agar dalam peroses pembriketan tidak lengket.

\section{Langkah Penelitian}

a. Persiapan Bahan Baku

Menyiapkan sampel (sekam padi), menyiapkan perekat tepung kanji.

b. Proses Karbonisasi

Sebelum di briket, sekam padi harus di karbonisasi dengan membakar sekam sampai membentuk arang.

c. Pembriketan

Dalam proses ini penggambungan antara sampel (sekam padi) dengan massa 100 gram dengan perekat $10 \%$ dari massa sekam padi kemudian di kempa dengan tekanan yang bervariasi yaitu 20 PSI, 30 PSI, 40 PSI. Sehingga menjadi berbentuk briket wafer.

d. Pengeringan 
Setelah pemberiketan maka proses selanjutnya yaitu pengeringan dengan menggunakan oven.

\section{Analisis Data}

a. Densitas

Densitas atau rapat jenis $(\rho)$ suatu zat adalah ukuran untuk konsentrasi zat tersebut dan dinyatakan dalam massa persatuan volume. Densitas memiliki pengaruh signifikan karena berbanding lurus dengan laju pembakaran. Semakin padat atau halus briket maka akan semakin lama waktu pembakaran (Darun, N., 2013). Nilai densitas dapat diperoleh dengan rumus di bawah ini:

$$
\rho=\frac{m}{V} \text {. }
$$

Keterangan :

$$
\rho=\text { densitas }\left(\mathrm{gram} / \mathrm{cm}^{3}\right)
$$

$m=$ massa biobriket (gram)

b. Nilai Kalor

$$
V=\text { Volume biobriket }\left(\mathrm{cm}^{3}\right)
$$

Nilai kalor adalah jumlah energi panas maksimum yang dilepaskan atau ditimbulkan oleh suatu bahan bakar melalui reaksi pembakaran sempurna per satuan massa atau volume bahan bakar tersebut. Nilai kalor diperoleh dari briket dengan data laboratorium menggunakan kalorimeter. Rumus untuk menentukan nilai kalor yaitu:

$$
\begin{aligned}
& Q=m \times c \times \Delta T \ldots \ldots . .(2.2) \\
& \text { Keterangan : } \\
& Q=\text { Nilai Kalor (Joule) } \\
& m=\text { Massa air }(\mathrm{kg}) \\
& c=\text { Kalor jenis air }(\mathrm{J} / \mathrm{kgK}) \\
& \Delta T=\text { Perubahan Suhu (K) }
\end{aligned}
$$

c. Kadar Air

Kadar air sangat menetukan kualitas dari bahan bakar. Semakin tinggi kadar air akan menyebabkan kualitas briket menurun, terutama akan berpengaruh terhadap nilai kalor dan briket akan sulit untuk dinyalakan (Darun, N ., 2013)

Cara pengujian kadar air dengan metode (ASTM D-3173)

- Cawan yang telah dibersihkan kemudian dioven dengan suhu 105 0C selama 1 jam.

- Dinginkan dalam desikator beberapa saat, kemudian ditimbang.
- Timbang massa cawan dan massa sampel sebanyak 2 gram.

- Sampel dikeringkan dengan suhu 105 OC selama kurang lebih 3 jam.

- Sampel kemudian didinginkan selam 1 jam dan ditimbang.

Persamaan yang digunakan untuk menghitung nilai kadar air yaitu

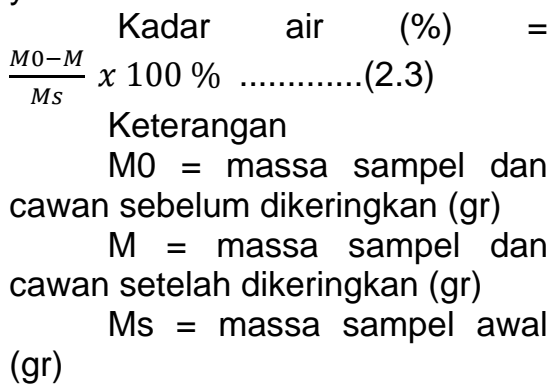

\section{d. Laju Pembakaran}

Pengujian laju pembakaran adalah proses pengujian dengan cara membakar briket untuk mengetahui lama nyala suatu bahan bakar, kemudian menimbang massa briket yang terbakar. Lamanya waktu penyalaan dihitung menggunakan stopwatch dan massa briket ditimbang dengan timbangan digital (Almu dkk, 2014).

Persamaan yang digunakan untuk mengetahui laju pembakaran adalah:

Laju Pembakaran $=\frac{m}{t} \ldots \ldots$

Keterangan :

$m$ = massa briket terbakar (massa briket awal

$$
\text { - massa briket sisa) (gram) }
$$

$t$ = waktu pembakaran (menit)

Dalam pembuatan briket harus mengacu pada standar kualitas agar tercapai kualitas yang optimal.

Brikut tabel standar kualitas briket arang dari beberapa Negara.

Tabel 1. Standar Kualitas Briket Arang Jepang, Inggris, Amerika, dan Indonesia

\begin{tabular}{lcccc}
\hline Sifat & \multicolumn{4}{c}{ Standar Mutu } \\
\cline { 2 - 5 } & Jepang & Inggri & US & SNI \\
& & s & A & \\
\hline Kadar Air (\%) & 6 s/d 8 & 3,6 & 6,2 & $<8$ \\
\hline $\begin{array}{l}\text { Kadar Abu } \\
\text { (\%) }\end{array}$ & 3 s/d 6 & 5,9 & 8,3 & $<8$ \\
\hline $\begin{array}{l}\text { Kadar Zat } \\
\text { Terbang (\%) }\end{array}$ & 15 s/d 30 & 16,4 & 19 & $<15$ \\
& & & - & \\
\hline $\begin{array}{l}\text { Kadar Karbon } \\
\text { Terikat (\%) }\end{array}$ & 60 s/d 80 & 75,3 & 60 & $>77$ \\
& & & & \\
\end{tabular}




\begin{tabular}{|c|c|c|c|c|}
\hline $\begin{array}{l}\text { Kerapatan } \\
\left(\mathrm{gr} / \mathrm{cm}^{3}\right)\end{array}$ & $1-1,2$ & 0,46 & 1 & 0,44 \\
\hline $\begin{array}{l}\text { Kuat Tekan } \\
\left(\mathrm{kg} / \mathrm{cm}^{2}\right)\end{array}$ & $60-65$ & 12,7 & 62 & 50 \\
\hline $\begin{array}{l}\text { Nilai Kalor } \\
\text { (kcal/gr) }\end{array}$ & $\begin{array}{c}6000 \mathrm{~s} / \mathrm{d} \\
7000\end{array}$ & 7300 & $\begin{array}{l}65 \\
00\end{array}$ & $\begin{array}{l}> \\
500 \\
0\end{array}$ \\
\hline
\end{tabular}

Sumber : Mangkau, dkk (2011)

Tabel 1 diatas merupakan dasar untuk membandingkan kualitas briket yang dihasilkan. Standar kualitas briket Indonesia untuk kerapatan yaitu $0,44\left(\mathrm{gr} / \mathrm{cm}^{3}\right)$, apabila kerapatan briket yang dihasilakn kurang dari $0,44\left(\mathrm{gr} / \mathrm{cm}^{3}\right)$, maka briket tersebut memiliki kualitas tidak bagus, apabila kerapatan briket lebih besar dari 0,44 $\left(\mathrm{gr} / \mathrm{cm}^{3}\right)$, maka kualitas briket semakin bagus. Standar kualitas briket Indonesia untuk nilai kalor yatu sebesar 5000 (kcal/gr), apabila nilai kalor briket yang dihasilakn kurang dari 5000 (kcal/gr), maka briket tersebut memiliki kualitas tidak bagus, apabila nilai kalor briket lebih besar dari 5000 (kcal/gr), maka kualitas briket semakin bagus. Standar kualitas briket Indonesia untuk kadar air yaitu $8 \%$, apabila kadar air briket yang dihasilakn kurang dari $8 \%$, maka briket tersebut memiliki kualitas bagus, apabila kadar air briket lebih besar dari $8 \%$, maka kualitas briket tidak bagus.

\section{HASIL DAN PEMBAHASAN}

Dalam penelitian yang berjudul "Uji Laju Pembakaran dan Nilai Kalor Briket Wafer Sekam Padi dengan Variasi Tekanan" dengan menggunakan bahan dasar sekam padi dan tepung kanji sebagai perekat sehingga kedua bahan dicampur dan dibriket dengan cetakan yang membentuk wafer dengan variasi tekanan $20 \mathrm{PSI}$ (pound per square inch), $30 \mathrm{PSI}$, dan 40 PSI. Bentuk dari briket wafer terlihat seperti pada Gambar 4.1 di bawah.

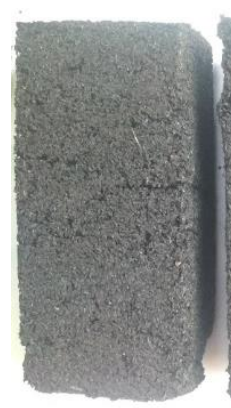

(a)

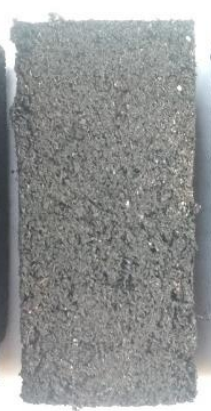

(b)

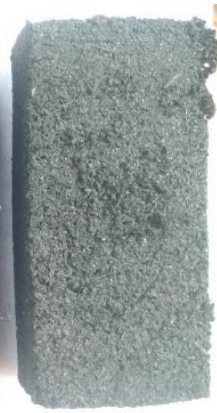

(c)
Gambar 1. Briket wafer sekam padi dengan tekanan (a) 20 PSI (b) 30 PSI (c) 30 PSI

Briket kemudian dioven dengan suhu 110 ${ }^{0} \mathrm{C}$ selama 2 jam. Pengovenan berfungsi untuk mengurangi kadar air dalam briket dan akan mengurangi massa briket. Untuk mengetahui kualitas dari briket wafer sekam padi yang dihasilkan, perlu dilakukan pengujian seperti densitas, kadar air, nilai kalor, dan laju pembakaran. Berikut hasil uji briket wafer sekam padi yeng telah dilakukan.

\section{Analisa Densitas Briket}

Densitas atau rapat jenis $(\rho)$ suatu zat adalah ukuran untuk konsentrasi zat tersebut dan dinyatakan dalam massa persatuan volume. Densitas memiliki pengaruh signifikan terhadap laju pembakaran. Sehingga kualitas briket juga ditentukan dari densitas briket. Nilai densitas dari briket wafer sekam padi dapat dilihat dalam Tabel 2 di bawah ini.

Tabel 2. Nilai densitas briket wafer sekam padi

\begin{tabular}{lllll}
\hline $\mathrm{N}$ & $\begin{array}{l}\text { Tekana } \\
\mathrm{0}\end{array}$ & $\begin{array}{l}\text { Massa } \\
\text { briket } \\
(\mathrm{gram})\end{array}$ & $\begin{array}{l}\text { Volum } \\
\text { e briket } \\
\left(\mathrm{cm}^{3}\right)\end{array}$ & $\begin{array}{l}\text { Massa } \\
\text { jenis } \\
\boldsymbol{\rho}(\boldsymbol{g r} / \\
\left.\mathbf{c m}^{\mathbf{3}}\right)\end{array}$ \\
\hline 1 & 20 & 104,7 & 231 & 0,453 \\
\hline 2 & 30 & 107,9 & 231 & 0,467 \\
\hline 3 & 40 & 115,6 & 231 & 0,500 \\
\hline
\end{tabular}

Secara lengkap densitas dari briket wafer sekam padi yang dihasilkan dapat dilihat pada Gambar 2 di bawah ini.

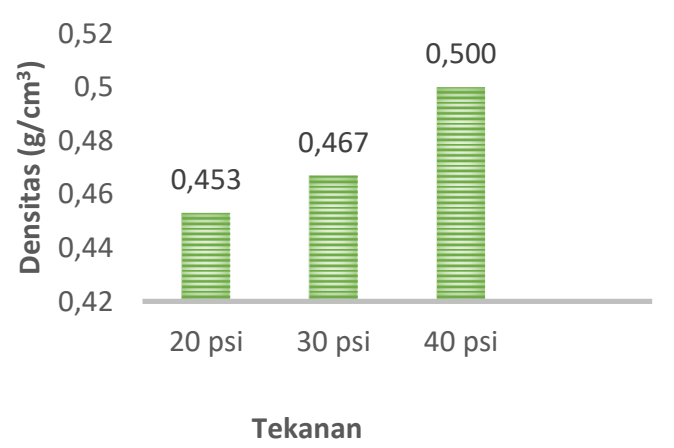

Gambar 2. Grafik densitas briket wafer sekam padi dengan perekat tapioka

Densitas briket wafer sekam padi yang dihasilkan berkisar antara $0,453 \mathrm{~g} / \mathrm{cm}^{3}-0,500$ $\mathrm{g} / \mathrm{cm}^{3}$. Briket wafer sekam padi yang dihasilkan yang memiliki nilai densitas terendah adalah pada sampel briket dengan tekanan 20 PSI. Sedangkan nilai densitas tertinggi pada sampel briket yang menggunakan tekanan $40 \mathrm{PSI}$.

\section{Analisis kadar air briket}

Kadar air adalah jumlah kandungan air yang terkandung dalam briket. Hasil uji kadar air dari briket wafer sekam padi yang telah dioven dengan suhu pengovenan $105^{\circ} \mathrm{C}$ selam 4 jam dapat dilihat pada Tabel 3 di bawah ini. 
Tabel 3. Hasil Kadar Air dari Briket Wafer Kesam Padi

\begin{tabular}{|c|c|c|c|c|c|}
\hline $\begin{array}{l}N \\
O\end{array}$ & $\begin{array}{l}\text { Te } \\
\text { ka } \\
\text { na } \\
n \\
\text { (P } \\
\text { SI) }\end{array}$ & $\begin{array}{l}\text { Massa } \\
\text { cawan+s } \\
\text { ampel } \\
\text { sebelum } \\
\text { pengove } \\
\text { nan } \\
\text { (gram) }\end{array}$ & $\begin{array}{l}\text { Massa } \\
\text { cawan } \\
\text { +samp } \\
\text { el } \\
\text { setelah } \\
\text { pengo } \\
\text { venan } \\
\text { (gram) }\end{array}$ & $\begin{array}{l}\text { Mass } \\
\text { a } \\
\text { sam } \\
\text { pel } \\
\text { Awal } \\
\text { (gra } \\
\text { m) }\end{array}$ & $\begin{array}{l}\text { Kad } \\
\text { ar } \\
\text { air } \\
(\%)\end{array}$ \\
\hline 1 & 20 & 49,171 & 49,042 & 2 & 6,45 \\
\hline 2 & 30 & 59,162 & 59,034 & 2 & 6,40 \\
\hline 3 & 40 & 51,791 & 51,678 & 2 & 5,65 \\
\hline
\end{tabular}

Secara lengkap hasil kadar air dari briket wafer sekam padi dapat di lihat pada Gambar 3 di bawah.

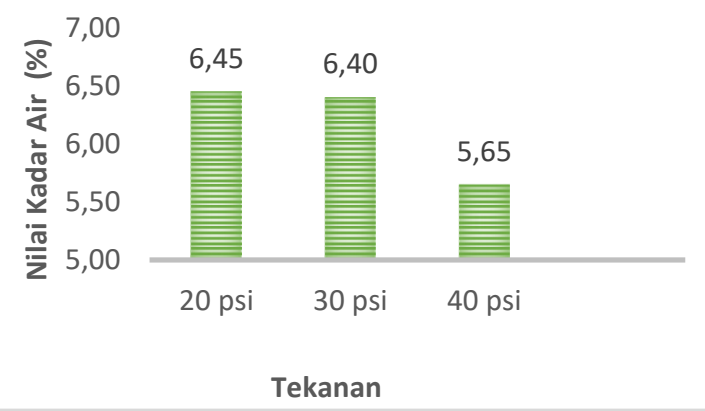

Gambar 3. Grafik nilai kadar air briket wafer sekam padi

Berdasarkan Tabel 3 bahwa kadar air yang dihasilkan berkisar antara 6,54 \% - 5,65\%. Kadar air pada briket dengan menggunakan tekanan $20 \mathrm{PSI}$ memiliki jumlah kadar air banyak dan briket dengan tekanan 40 PSI memiliki jumlah kadar air yang paling banyak.

\section{Analisa Nilai Kalor Briket}

Nilai kalor adalah jumlah energi panas maksimum yang ditimbulkan oleh suatu bahan bakar melalui reaksi pembakaran sempurna per satuan massa atau volume bahan bakar tersebut. Uji Nilai kalor dari briket wafer sekam padi yang dihasilkan dari tekanan $20 \mathrm{PSI}, 30$ PSI, dan 40 PSI bisa dilihat pada Tabel 4.

Tabel 4. Uji Nilai Kalor Briket Wafer Sekam Padi

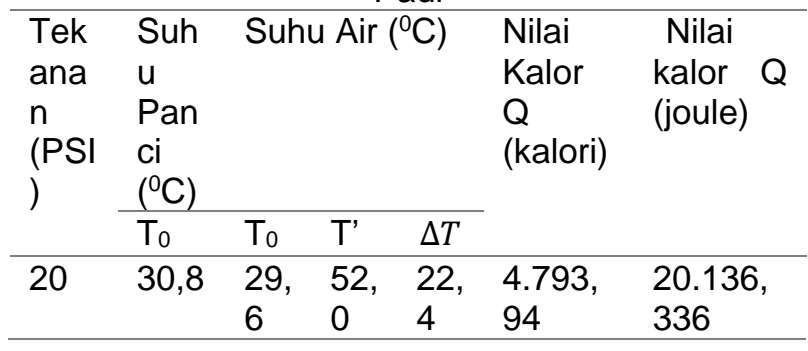

Volume 6, Nomor 2, November 2020.

p-ISSN : 2460-9587

e-ISSN : 2614-7017

\begin{tabular}{lllllll}
\hline 30 & 30,8 & 29, & 53, & 24 & 5.137, & 21.579, \\
& & 6 & 6 & & 64 & 984 \\
\hline 40 & 30,8 & 29, & 54, & 24, & 5.266, & 22.121, \\
& & 6 & 2 & 6 & 52 & 352 \\
\hline
\end{tabular}

Secara lengkap nilai kalor dari briket wafer sekam padi yang dihasilkan dapat dilihat pada Gambar 4 di bawah ini.

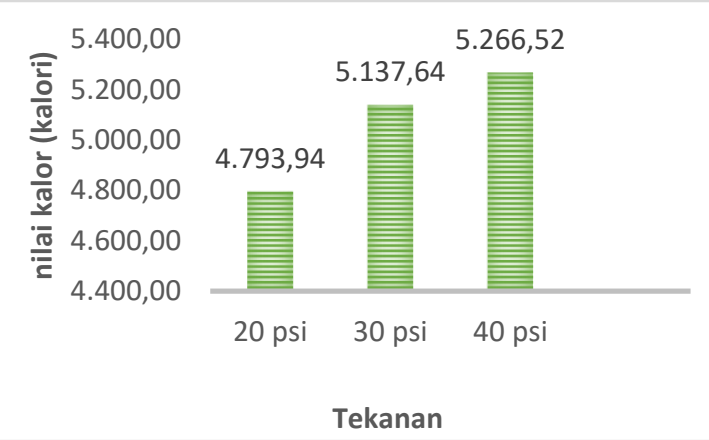

Gambar 4. Grafik nilai kalor briket wafer sekam padi

Dari Gambar 4 di atas dapat dilihat bahwa nilai kalor dari riket wafer sekam padi berkisar antara 4.793,94 kalori - 5.266,52 kalori. Adapun briket yang dihasilkan yang memiliki nilai kalor terendah pada briket yang menggunakan tekanan 20 PSI. Sedangkan nilai kalor tertinggi pada briket yang menggunakan tekanan 40 PSI.

\section{Analisa Laju Pembakaran Briket}

Laju pembakaran merupakan kecepatan briket tersebut untuk habis terbakar. Artinya semakin besar nilai laju pembakaran, maka semakin cepat briket tersebut untuk habis. Laju pembakaran dari briket wafer sekam padi dengan tekanan $20 \mathrm{PSI}, 30 \mathrm{PSI}$, dan $40 \mathrm{PSI}$ didapatkan hasil bahwa briket dengan tekanan 20 PSI mengalami nilai laju pembakaran yang paling cepat. Hasil dari laju pembakaran dapat dilihat pada Tabel 5 di bawah ini.

Tabel 5. Nilai Laju Pembakaran Briket Wafer Sekam Padi

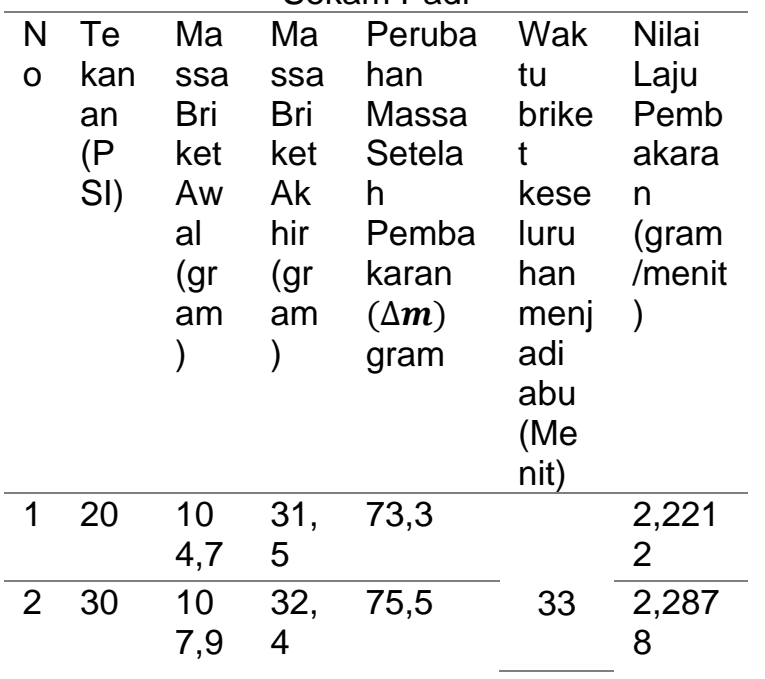




$\begin{array}{llllll}3 & 40 & 11 & 35, & 80,4 & 2,436 \\ & & 5,6 & 2\end{array}$

Secara lengkap nilai laju pembakaran dari briket yang dihasilkan dapat dilihat pada Gambar 5 dibawah ini.

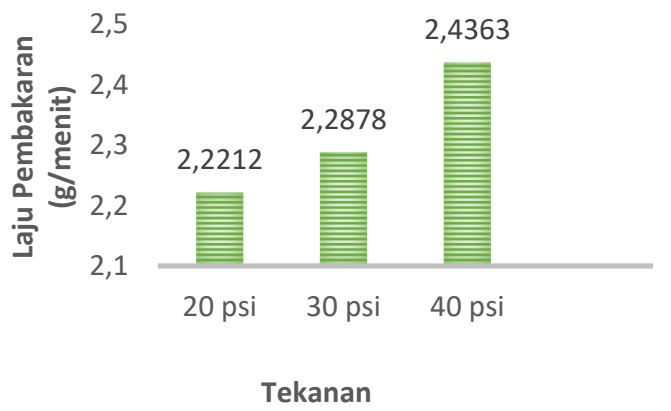

Gambar 5. Grafik Laju Pembakaran Briket

Dari Gambar 5 di atas dapat dilihat bahwa nilai laju pembakaran briket wafer sekam padi berkisar antara 2,2212 gram/menit - 2,4363 gram/menit. Briket dengan laju pembakaran terendah ialah pada tekanan 20 PSI dan briket dengan laju pembakaran yang tertingg yaitu 40 PSI. Laju pembakaran briket dalam gambar 4.5 yaitu semakin tinggi seiring dengan peningkatan tekanan pada briket wafer sekam padi.

Dari hasil analisis data di atas yang dikerjakan dengan perlakuan tekanan berbeda, didapatkan bahwa nilai densitas yang paling tinggi yaitu dengan tekanan 40 PSI yaitu 0,500 gram $/ \mathrm{cm}^{3}$ selanjutnya $30 \mathrm{PSI}$ yaitu 0,467 $\mathrm{gram} / \mathrm{cm}^{3}$ dan yang terakhir 20 PSI yaitu 0,463 $\mathrm{gram} / \mathrm{cm}^{3}$. Densitas yang dihasilkan dari briket wafer sekam padi dengan variasi tekanan semakin tinggi seiring penambahan tekanan. Dari hasil penelitian di atas diketahui nilai densitas yang paling tinggi yaitu pada tekanan $40 \mathrm{PSI}$, ini disebabkan karena penambahan massa bahan yang semakin banyak untuk membuat briket yang mempunyai volume yang sama. Nilai dari kerapatan briket dengan tekanan $40 \mathrm{PSI}$ sesuai dengan standar kualitas briket nasional (SNI) yaitu memiliki kerapatan lebih dari $0,44 \mathrm{gr} / \mathrm{cm}^{3}$.

Nilai analisis dari kadar air briket wafer sekam padi bertujuan untuk mengetahui jumlah kadar air yang terkandung dalam briket. Dari hasil uji yang telah dilakukan didapatkan bahwa kadar air dengan tekanan $20 \mathrm{PSI}$ sebesar $6,45 \%$, tekanan $30 \mathrm{PSI}$ sebesar 6,40\%, dan tekanan $40 \mathrm{PSI}$ sebesar 5,65\%. Diketahui bahwa tekanan 40 PSI memiliki kadar air yang paling rendah yaitu sebesar $5,65 \%$, ini dikarenakan pada campuran antara tepung kanji dan sekam padi ditekan dengan tekanan yang lebih kuat akan menyebabkan kadar air pada sampel semakin berkurang sehingga menyebabkan nilai kalor pada tekanan 40 PSI memiliki nilai kalor yang paling besar. Nilai dari kadar air briket dengan variasi tekanan sesuai dengan standar kualitas briket nasional (SNI) yaitu kadar air tidak melebihi $8 \%$.

Nilai kalor merupakan energi panas yang dihasilkan melalui pembakaran sempurna dari briket. Dari hasil uji nilai kalor dengan menggunakan persamaan (2.3) didapatkan hasil dengan tekana $40 \mathrm{PSI}$ yaitu sebesar 5.266,52 kalori, 30 PSI yaitu sebesar 5.137,64 kalori, dan pada tekanan 20 PSI yaitu sebesar 4.793,94 kalori. Diketahui bahwa nilai kalor yang paling besar dihasilkan dengan tekanan 40 PSI. Faktor yang mempengaruhi hal ini dikarenakan tekanan yang semakin besar menyebabkan nilai densitas dari briket semakin tinggi dan kadar air dari briket semakin berkurang dan transfer panas pada briket akan lebih cepat. Ini sejalan dengan penelitian (Jamilatun, 2008) bahwa kerapatan dari briket akan mempengaruhi nilai kalor, semakin tinggi kerapatan dari briket maka semakin tinggi nilai kalor yang dihasilkan.

Analisis nilai laju pembakaran bertujuan untuk mengetahui kecepatan briket terbakar sampai menjadi abu. Hasil analisis laju pembakaran dengan tekanan yang berbeda diketahui bahwa tekanan 20 PSI yaitu sebesar 2,2212 (gram/menit), tekanan 30 PSI sebesar 2,2878 (gram/menit), dan tekanan $40 \mathrm{PSI}$ sebesar 2,4363 (gram/menit). Dari perlakuan terhadap briket diketahui bahwa, briket yang ditekan dengan tekanan yang bervariasi akan menghasilkan laju pembakaran yang berbeda. Nilai laju pembakaran yang paling rendah yaitu pada briket dengan tekanan $20 \mathrm{PSI}$ sebesar 2,2212 (gram/menit) dan nilai laju pembakaran yang paling tinggi yaitu pada briket dengan tekanan $40 \mathrm{PSI}$ sebesar 2,4363 (gram/menit). Dari hasil penelitian di atas diketahui laju pembakaran yang paling tinggi yaitu pada tekanan 40 PSI. Faktor yang mempengaruhi hal ini dikarenakan kandungan kadar air pada briket dengan tekanan 40 PSI lebih rendah dari pada briket dengan tekanan 20 PSI dan 30 PSI sehingga menyebabkan transfer panas kepermukaan briket tersebar secara merata.

\section{SIMPULAN DAN SARAN Simpulan}

Dari hasil penelitian yang telah dilakukan briket wafer sekam padi dengan tekana yang berbeda mempengaruhi nilai kalor yang dihasilkan. Briket dengan tekanan 20 PSI menghasilkan nilai kalor yaitu sebesar 4.793,94 kalori, tekanan 30 PSI yaitu sebasar $5.137,64$ kalori, dan tekanan $40 \mathrm{PSI}$ menghasilkan $5.266,52$ kalori. Nilai kalor dengan tekanan 40 PSI menghasilkan nilai kalor yang paling tinggi. 
Sedangkan laju pembakaran yang dihasilkan dengan tekanan 20 PSI yaitu sebesar 2,2212 (gram/menit), tekanan 30 PSI sebasar 2,2878 (gram/menit), dan tekanan $40 \mathrm{PSI}$ sebesar 2,4363 (gram/menit). Laju pembakaran yang paling tinggi dihasilkan pada tekanan $40 \mathrm{PSI}$. Semakin besar tekanan yang diberikan maka nilai kalor dan laju pembakaran yang dihasilkan semakin tinggi.

\section{Saran}

Dari uji laju pembakaran dan nilai kalor briket wafer sekam padi dengan variasi tekananan untuk penelitian selanjutnya perlu dilakukan penelitian untuk mengetahui kadar abu yang dihasilkan dengan variasi tekanan.

\section{UCAPAN TRIMAKASIH}

Trimakasih kami ucapkan kepada laboratorim kimia dan fisika UNDIKMA karena telah mengizinkan dan membantu kami dalam penelitian.

\section{DAFTAR RUJUKAN}

Agustina, S. E. \& Syafrian A. (2005). Mesin Pengempa Briket Limbah Biomassa, Salah Satu Solusi Penyediaan Bahan Bakar Pengganti BBM untuk Rumah Tangga dan Industri Kecil. Makalah disajikan dalam Seminar Nasional dan Kongres Perteta, Bandung.

Almu, M. A., Syahrul, S., \& Padang, Y. A. (2014). ANALISA NILAI KALOR DAN LAJU PEMBAKARAN PADA BRIKET CAMPURAN BIJI NYAMPLUNG (Calophyllm Inophyllum) DAN ABU SEKAM PADI. Dinamika Teknik Mesin. https://doi.org/10.29303/d.v4i2.61

Anonim. (2019). Pemprov Minta Petani Tembakau Tak Khawatir, (Online), https://www.suarantb.com/ekonomi.da n.bisnis/2019/06/271598/Pemprov.Min ta.Petani.Tembakau.Tak.Khawatirl, diakses 9 Desember 2019)

Arni, Labania, H. M., \& Nismayanti, A. (2014). Studi Uji Karakteristik Fisis Briket Bioarang sebagai Sumber Energi Alternatif. Online Jurnal of Natural Science.

Darun, N. (2013). Pengaruh Variasi Temperatur Cetakan Terhadap Karakteristik Briket Kayu Sengon Pada Tekanan Kompaksi 5000 Psig. Disertasi tidak diterbitkan. Semarang: Universitas Negeri Semarang.

Hamidi, hirwan (2017). Keterkaiatan antara pelaku dan implikasinya terhadap keberlanjutan kemitraan agribisnis tembakau Virginia di pulau Lombok.
Agreteksos vol.17 No. 3 desember 2007.

Hasil Observasi (2019) Petani Tembakau di Desa Jerowaru Kecamatan Jerowaru Kabupaten Lombok Timur NTB

Profil Desa Jerowar (2020). Pemanfaatan Lahan di Desa Jerowaru, Kecamatan Jerowaru, Kabupaten Lombok Timur NTB.

Jamilatun, S. (2012). Sifat-Sifat Penyalaan dan Pembakaran Briket Biomassa, Briket Batubara dan Arang Kayu. Jurnal Rekayasa Proses, 2(2). https://doi.org/10.22146/jrekpros.554

Muhammad Kadri dan Rugaya, (2013) Pemanfaatan Briket Sekam Padi Sebagai Bahan Bakar Alternatif Pengganti Minyak Tanah, 2013

Patabang, D. (2012). Karakteristik Termal Briket Arang Sekam Padi Dengan Variasi Bahan Perekat. Jurnal Mekanikal.

Sudiro, \& Suroto, S. (2014). Pengaruh Komposisi dan Ukuran Serbuk Briket yang terbuat dari Batubara dan Jerami Padi terhadap Karakteristik Pembakaran. Sainstech Politeknik Indonusa Surakarta. 